\title{
Approximate classification of mining tremors harmfulness based on free-field and building foundation vibrations
}

\author{
Krystyna Kuzniar ${ }^{1, *}$, Krystyna Stec $^{2}$, and Tadeusz Tatara ${ }^{3}$ \\ ${ }^{1}$ Pedagogical University of Cracow, Institute of Technology, Krakow, Poland \\ ${ }^{2}$ Central Mining Institute, Department of Geology and Geophysics, Katowice, Poland \\ ${ }^{2}$ Cracow University of Technology, Institute of Structural Mechanics, Krakow, Poland
}

\begin{abstract}
The paper compares the results of an approximate evaluation of mining tremors harmfulness performed on the basis of free-field and simultaneously measured building foundation vibrations. The focus is on the office building located in the Upper Silesian Basin (USB). The empirical Mining Intensity Scale GSI-GZW $\mathrm{KW}_{-2} 2012$ has been applied to classify the harmfulness of the rockbursts. This scale is based on the measurements of free-field vibrations but, for research purposes, it was also used in the cases of building foundation vibrations. The analysis was carried out using the set of 156 pairs ground - foundation of velocity vibration records as well as the set of 156 pairs of acceleration records induced by the same mining tremors.
\end{abstract}

Keywords: mining tremors, GSI scale, harmfulness of vibrations, ground vibrations, foundation vibrations

\section{Introduction}

So called paraseismic sources - for example, mining tremors, can induce ground motions. Mining tremors have been observed in many countries all over the world. These phenomena refer to underground exploitation of coal, copper, and gold mines in China, Australia, South Africa, Canada, India, France, Czech Republic, Russia, and Poland [1]. They are random events with respect to their time, place and magnitude, as with earthquakes. The energy of these phenomena is smaller than in earthquakes but can induce negative influence on structures. Mining-induced ground motion is a hazard to surface structures, as ground motions can result in their damage.

In Poland active seismicity and rockbursts are substantial problems e.g. in Upper Silesian Basin (USB) which is the most seismically active mining region in Poland. The mining-induced seismicity hazard in this area has been recently increased. The intensity of

* Corresponding author: krystyna.kuzniar@up.krakow.pl 
mining-induced seismic events growing and has stated dangerous for surface structure as well as underground facilities.

Records of mining-induced vibrations (referring to acceleration and velocity) simultaneously registered on the free-field close to a building, and at the foundation level of the building, can differ significantly in this area. It is common property for free-field (ground) and building foundation vibrations in mining areas [1]. It can be observed to maximal values of acceleration and velocity, to response spectra as well as the bands of dominant frequencies. These differences can be explained by the soil-structure interaction effect.

Convenient in practice, simple, approximate method of assessing the harmfulness of vibration of mining buildings is the use of properly prepared scales [2-6]. These scales allow you to determine the degree of vibration intensity and further to estimate their effect on buildings. They are based on soil vibration parameters (e.g. vibration velocity, duration of intense vibration phase). Meanwhile, the vibrations measured on the foundations of buildings may differ significantly from the vibrations recorded on the ground next to the buildings [7-11]. The results presented in [12] indicate that accurate determination of the vibration hazard for buildings is possible on the basis of vibrations of the foundation.

This paper is focused on approximate classification of mining tremors harmfulness based on free-field and simultaneously recorded building foundation vibrations. The research refers to approximate way for assessing the harmfulness of mine-induced vibrations to an actual low-rise office building. To do this, one can use appropriately prepared scales. These scales use the recorded ground or building foundation vibrations and their parameters.

In this study the assessment of the surface vibration intensity according to the GSI$\mathrm{GZW}_{\mathrm{KW}}-2012$ scale was conducted using simultaneously recorded free-field vibration patterns alongside the building and, for cognitive purposes, vibrations of foundations of the building. The influence of the surface vibration measurement site on the degree of vibration intensity was analysed. The Mining Intensity Scale GSI-GZW $\mathrm{KW}_{-}-2012$ has been applied in velocity version (the basis scale) as well as acceleration version (supporting version) [1315]. Additionally, the impact of the vibration measurement site (ground next to the building or foundation of the building) on the compatibility of the degree of intensity according to the GSI-GZW $\mathrm{KW}-2012$ scale in velocity (GSI-GZW $\left.\mathrm{KW}_{\mathrm{W}}-2012-\mathrm{V}\right)$ and acceleration (GSI$\left.\mathrm{GZW}_{\mathrm{KW}}-2012-\mathrm{A}\right)$ versions was investigated.

\section{Experimental tests}

Mine-induced rockbursts in the Upper Silesian Basin (USB) were the sources of the analysed vibrations. The analysis of the vibration harmfulness is based on the free-field and simultaneously measured building foundation vibrations.

The focus is on the actual masonry office (administrative) building. It is a low-rise (2storey) building with plan dimensions of $23.8 \mathrm{~m} \times 12.5 \mathrm{~m}$ and $7.30 \mathrm{~m}$ high. Bearing walls of the building constitute a mixed transverse-longitudinal system. There is no basement in the considered building and it is founded directly on the ground using concrete strip foundations at a depth of $1.4 \mathrm{~m}$. The sub-soil consists of a soil layer, medium and fine sand and partially yellow dust.

Acceleration records of free-field vibrations next to the building and on the building foundation were measured simultaneously using so-called "an armed partition" accelerometers. The main attention was devoted to measurements of the horizontal vibration components in the directions parallel to the transverse and longitudinal axis of the building because of the effects of mine-induced rockbursts on a building, as well as the size of building geometric parameters. The records of component vibration velocities were 
obtained by the acceleration records integration. Resultant accelerations and resultant velocities of free-field and foundation vibrations were computed on the basis of horizontal vibration components in both directions.

Records induced by mining tremors with energies included in the range of $1.0 \cdot 10^{5} \mathrm{~J}-$ $4.0 \cdot 10^{9} \mathrm{~J}$ and epicentral distances included in the range of $230 \mathrm{~m}-2045 \mathrm{~m}$ were taken into account. The analysis was carried out using the set of 156 pairs ground - foundation of velocity vibration records as well as the set of 156 pairs of acceleration records induced by the same mining tremors.

The ranges of the maximum values of the resultant free-field and foundation horizontal accelerations obtained using the components of the recorded horizontal vibrations filtered in the band to $10 \mathrm{~Hz}\left(P G A_{H 10}\right.$ and $P F A_{H 10}$ respectively), as well as the ranges of the maximum values of the resultant free-field and foundation horizontal velocities $\left(P G V_{H}\right.$ and $P F V_{H}$ respectively) are listed in Table 1.

Table 1. The ranges of the maximum values of the resultant free-field and foundation horizontal vibrations: $P G A_{H 10}, P F A_{H 10}, P G V_{H}, P F V_{H}$.

\begin{tabular}{|c|c|c|c|}
\hline & & \multicolumn{2}{|c|}{ Values } \\
\hline & & Minimum & Maximum \\
\hline \multirow{2}{*}{ Accelerations } & $P G A_{H 10}\left[\mathrm{~m} / \mathrm{s}^{2}\right]$ & 0.01 & 1.69 \\
\hline & $P F A_{H 10}\left[\mathrm{~m} / \mathrm{s}^{2}\right]$ & 0.01 & 2.29 \\
\hline \multirow{2}{*}{ Velocities } & $P G V[\mathrm{~m} / \mathrm{s}]$ & 0.0004 & 0.0557 \\
\hline & $P F V[\mathrm{~m} / \mathrm{s}]$ & 0.0015 & 0.0909 \\
\hline
\end{tabular}

\section{Approximate estimation of the intensity of mine-induced surface vibrations using recorded free-field and building foundation vibrations}

\subsection{The Mining Intensity Scale GSI-GZW $\mathrm{KW}_{\mathrm{K}}-2012$}

GSI-GZW $\mathrm{KW}-2012$ scale is an empirical-measurement scale for monitoring and assessing the impact of mining shocks induced in the Upper Silesian Basin (USB) on surface development and perceptibility of vibration by humans [13-15]. It refers to buildings, linear underground infrastructure facilities (underground water, gas, sewage or other networks (e.g. tunnels)). This scale exists in velocity (basis scale) and acceleration (the auxiliary scale) versions, respectively denoted as GSI-GZW $\mathrm{KW}_{-}-2012-\mathrm{V}$ and GSI-GZW $\mathrm{KW}_{\mathrm{W}}-2012-\mathrm{A}$. The GSI-GZW $\mathrm{KW}_{\mathrm{KW}}-2012$ scale associates macro-seismic effects of vibrations with the values of the parameters of surface vibrations, selected for the best description of the actual intensity of the vibrations.

With regard to buildings, the GSI-GZW $\mathrm{KW}_{-}-2012$ scale allows an approximate assessment of the impact of mining vibrations from harmless vibrations through causing architectural damages, up to the limit above which structural damages may occur. The scale distinguishes five degrees of vibration intensity listed in Table 2. Severity levels are attributed to damage that may occur in buildings. The GSI-GZW $\mathrm{KW}_{\mathrm{KW}}-2012$ scale does not distinguish clearly the technical condition of the building.

The basic parameters necessary in assessing the impact of surface vibrations caused by rockbursts through the use of the scale GSI-GZW $\mathrm{KW}_{\mathrm{W}}-2012$, are: the maximum value of the resultant of the free-field horizontal velocity $P G V_{H}-$ scale $G S I-G_{\mathrm{KW}}-2012-\mathrm{V}$, the maximum value of the resultant free-field horizontal acceleration $P G A_{H 10}$, obtained on the 
basis of the filtered components of the recorded horizontal vibration in the band to $10 \mathrm{~Hz}-$ scale GSI-GZW $\mathrm{KW}_{-}-2012-\mathrm{A}$, and the duration of the intensive phase of vibrations $t_{H v}$ and $t_{\mathrm{Ha}}$ for the velocity and acceleration respectively [15].

Table 2. Effects of mining shocks referring to degrees of intensity in the GSI-GZW $\mathrm{KW}-2012$ scale.

\begin{tabular}{|c|l|}
\hline $\begin{array}{c}\text { Degree of vibration } \\
\text { intensity } \boldsymbol{I}\end{array}$ & \multicolumn{1}{c|}{$\begin{array}{c}\text { Description of effects according to the } \\
\text { GSI-GZW }\end{array}$} \\
\hline 0 & not noticeable; with no effect on buildings \\
\hline I & being felt; only sporadically causing an increase in existing damage \\
\hline II & $\begin{array}{l}\text { intensification of existing damage; enlargement of pre-existing damage to } \\
\text { non-structural elements }\end{array}$ \\
\hline III & $\begin{array}{l}\text { non-structural damages; first damages of non-structural elements; } \\
\text { extensive enlargement of existing damages to non-structural elements }\end{array}$ \\
\hline IV & structural damages; single damages of structural elements \\
\hline
\end{tabular}

\subsection{Application of the scale GSI-GZW $\mathrm{KW}_{\mathrm{KW}} 2012$ for the evaluation of harmfulness of the analysed vibrations}

Graphical illustration of the results of intensity assessment of the free-field vibrations induced by the 156 analysed rockbursts in the cases of GSI-GZW $\mathrm{KW}-2012-\mathrm{V}$ scale as well as GSI-GZW $\mathrm{KW}-2012-\mathrm{A}$ scale applications are shown in Fig. 1 and Fig. 2 respectively. Additionally, for the comparison, analogous results related to the simultaneously measured foundation vibrations are also included in these figures. Next, in Fig. 3 and Fig. 4, the comparisons of the degrees of intensity of free-field and building foundation vibrations determined using the two versions of scales in the cases of the 156 successive rockbursts are presented.

It is visible that some differences can occur in the vibration intensity evaluation depending on the place of simultaneously registration - free-field or building foundation (cf. Fig. 1 - Fig. 4). Besides, the "shift" into the longer durations of the intensive phases of foundation vibrations for the velocities as well as accelerations $\left(t_{H v}\right.$ and $\left.t_{H a}\right)$ can be observed in the case of intensity assessments based on foundation vibrations in comparison to intensity assessments based on free-field vibrations (cf. Fig. 1, Fig. 2). It should also be noted that the distributions of the maximum values of the resultant velocities as well as accelerations in the cases of the free-field and foundation vibrations are different despite of the same set of rockbursts - the sources of vibrations.

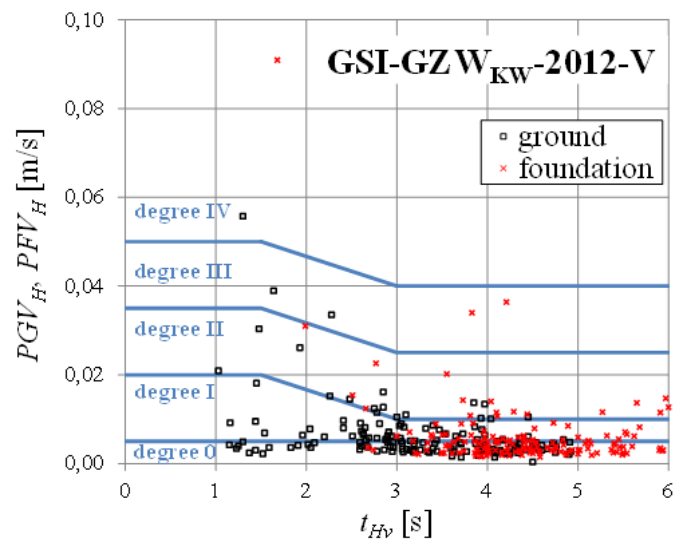

Fig. 1. Results of the assessment of the intensity of surface vibrations induced by the considered mining tremors using the scale GSI-GZW $\mathrm{KW}-2012-\mathrm{V}$. 


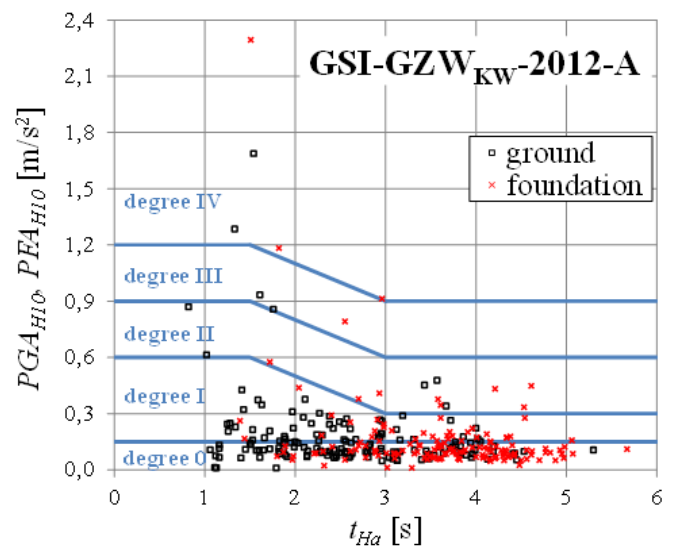

Fig. 2. Results of the assessment of the intensity of surface vibrations induced by the considered mining tremors using the scale GSI-GZW $\mathrm{KW}$-2012-A.

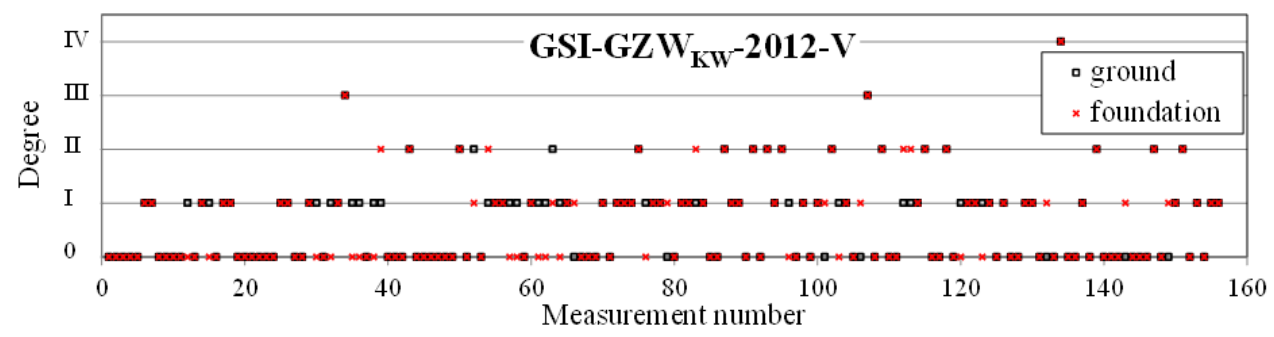

Fig. 3. Comparison of the degrees of intensity of free-field and building foundation vibrations determined using the scale GSI-GZW $\mathrm{KW}-2012-\mathrm{V}$ in the cases of the successive rockbursts.

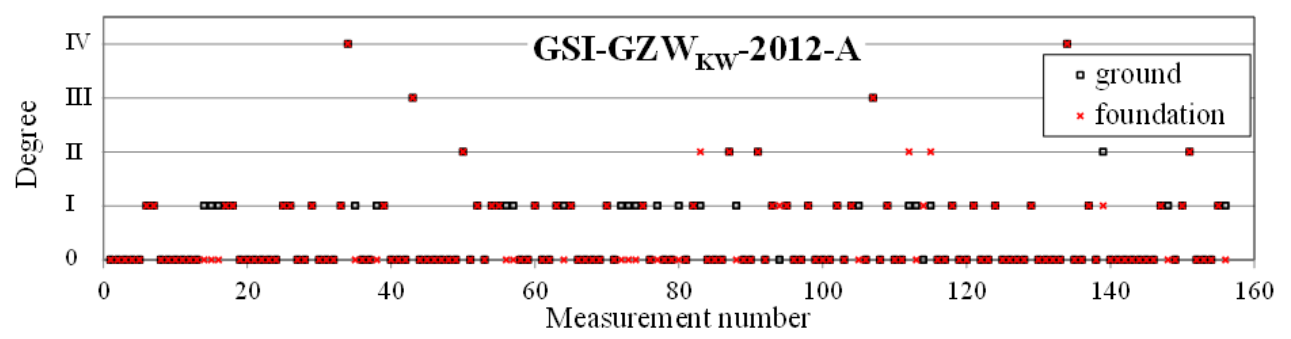

Fig. 4. Comparison of the degrees of intensity of free-field and building foundation vibrations determined using the scale GSI-GZW $\mathrm{KW}-2012-\mathrm{A}$ in the cases of the successive rockbursts.

Table 3 shows the list regarding the rockbursts for which compatibility of the intensity assessments was obtained in the cases of the free-field and foundation vibrations, whereas Table 4 presents the list regarding the mining tremors for which compatibility of the intensity assessments was not obtained in the cases of the ground and foundation vibrations.

Looking at the results collected in Table 3 it can be stated that in the cases of about $80 \%$ of all (156) shocks the compatibility of the intensity assessments based on the simultaneously measured free-field and foundation vibrations was obtained using the velocity version of scale GSI-GZW $\mathrm{KW}_{\mathrm{K}}-2012-\mathrm{V}(80.1 \%)$, as well as using the acceleration version of scale GSI-GZW $\mathrm{KW}_{\mathrm{K}}-2012-\mathrm{A}(84.6 \%)$.

Among the rest considered cases of mine-induced tremors (without the compatibility of the vibration intensity assessments based on the free-field and foundation vibrations) the straight majority of vibration intensity assessments with higher degrees of vibrations 
intensity for the free-field vibrations than for the foundation vibrations were denoted according both to velocity (61.3\%) and acceleration (79.2\%) versions of GSI-GZW $\mathrm{KW}-2012$ scale (cf. Table 4).

Table 3. List regarding the rockbursts for which compatibility of the intensity assessments was obtained in the cases of the free-field and foundation vibrations.

\begin{tabular}{|c|c|c|c|c|c|}
\hline \multicolumn{3}{|c|}{ GSI-GZW $_{\mathbf{K W}} \mathbf{- 2 0 1 2 - V}$} & \multicolumn{3}{c|}{ GSI-GZW $_{\mathbf{K W}} \mathbf{- 2 0 1 2 - A}$} \\
\hline $\begin{array}{c}\text { Intensity } \\
I\end{array}$ & $\begin{array}{c}\text { Number of } \\
\text { shocks }\end{array}$ & $\begin{array}{c}\text { Percentage of } \\
\text { all (156) shocks }\end{array}$ & $\begin{array}{c}\text { Intensity } \\
I\end{array}$ & $\begin{array}{c}\text { Number of } \\
\text { shocks }\end{array}$ & $\begin{array}{c}\text { Percentage of } \\
\text { all (156) shocks }\end{array}$ \\
\hline 0 & 68 & $43.6 \%$ & 0 & 92 & $58.9 \%$ \\
\hline I & 40 & $25.6 \%$ & I & 32 & $20.5 \%$ \\
\hline II & 14 & $9.0 \%$ & II & 4 & $2.6 \%$ \\
\hline III & 2 & $1.3 \%$ & III & 2 & $1.3 \%$ \\
\hline IV & 1 & $0.6 \%$ & IV & 2 & $1.3 \%$ \\
\hline In total & 125 & $80.1 \%$ & In total & 132 & $84.6 \%$ \\
\hline
\end{tabular}

Table 4. List regarding the rockbursts for which compatibility of the intensity assessments was not obtained in the cases of the free-field and foundation vibrations.

\begin{tabular}{|c|c|c|c|c|c|}
\hline \multicolumn{3}{|c|}{ GSI-GZW $_{K W}-2012-V$} & \multicolumn{3}{|c|}{ GSI-GZW $_{\mathrm{KW}}$-2012-A } \\
\hline \multicolumn{2}{|c|}{ Intensity $I$} & \multirow{2}{*}{$\begin{array}{l}\text { Number of } \\
\text { shocks }\end{array}$} & \multicolumn{2}{|c|}{ Intensity $I$} & \multirow{2}{*}{$\begin{array}{c}\text { Number of } \\
\text { shocks }\end{array}$} \\
\hline free-field & foundation & & free-field & foundation & \\
\hline 0 & I & 7 & 0 & I & 2 \\
\hline I & 0 & 17 & I & 0 & 18 \\
\hline I & II & 5 & I & II & 3 \\
\hline II & I & 2 & II & I & 1 \\
\hline \multicolumn{2}{|c|}{ In total } & $31(19.9 \%)$ & \multicolumn{2}{|c|}{ In total } & $24(15.4 \%)$ \\
\hline
\end{tabular}

Table 5. Comparison of the compatibility of the free-field - foundation intensity assessments in the cases of the successive free-field vibration intensity degrees $(I G)$.

\begin{tabular}{|c|c|c|c|c|c|}
\hline \multicolumn{3}{|c|}{ GSI-GZW $_{K W}-2012-V$} & \multicolumn{3}{|c|}{ GSI-GZW $_{K W}-2012-A$} \\
\hline \multirow{2}{*}{$\begin{array}{c}G \\
\text { /Number } \\
\text { of shocks }\end{array}$} & \multicolumn{2}{|c|}{$\begin{array}{l}\text { Percentage of the } I \text { free-field - } \\
\text { foundation assessments }\end{array}$} & \multirow{2}{*}{$\begin{array}{c}\text { IG } \\
\text { /Number } \\
\text { of shocks }\end{array}$} & \multicolumn{2}{|c|}{$\begin{array}{l}\text { Percentage of the } I \text { free-field - } \\
\text { foundation assessments }\end{array}$} \\
\hline & compatible & not compatible & & compatible & not compatible \\
\hline $0 / 75$ & $90.7 \%$ & $9.3 \%$ & $0 / 94$ & $97.9 \%$ & $2.1 \%$ \\
\hline $\mathrm{I} / 62$ & $64.5 \%$ & $35.5 \%$ & $\mathrm{I} / 53$ & $60.4 \%$ & $39.6 \%$ \\
\hline II/16 & $87.5 \%$ & $12.5 \%$ & $\mathrm{II} / 5$ & $80.0 \%$ & $20.0 \%$ \\
\hline $\mathrm{III} / 2$ & $100.0 \%$ & $0.0 \%$ & $\mathrm{III} / 2$ & $100.0 \%$ & $0.0 \%$ \\
\hline IV/1 & $100.0 \%$ & $0.0 \%$ & $\mathrm{IV} / 2$ & $100.0 \%$ & $0.0 \%$ \\
\hline
\end{tabular}

Comparison of the compatibility of the ground - foundation intensity assessments in the cases of the successive free-field vibration intensity degrees $(I G)$ is shown in Table 5. Very fit results of intensity degrees of the free-field and foundation vibrations were determined in the cases of the free-field vibration intensity degrees: $I G-0, I G-$ III, $I G-I V$. This conclusion relates to GSI-GZW $\mathrm{KW}-2012-\mathrm{V}$ scale as well as GSI-GZW $\mathrm{KW}-2012-\mathrm{A}$ scale. 
But it is worth noting that the number of considered rockbursts with the III degree intensity and the IV degree intensity is not numerous. Hence boldly generalization is not possible in these groups of shocks. Relatively weak compatibility of the vibration intensity assessments based on the free-field and foundation vibrations concerns the first (I) and the second (II) degree of vibration intensity (cf. Table 5).

The influence of the vibration measurement site (ground next to the building or foundation of the building) on the compatibility of the degree of vibration intensity according to the GSI-GZW $\mathrm{KW}-2012$ scale in velocity (GSI-GZW $\mathrm{KW}-2012-\mathrm{V}$ ) and acceleration (GSI-GZW $\mathrm{KW}-2012-\mathrm{A}$ ) versions is presented in Table 6 and Table 7. It can be stated from the results collected in Table 6 that the similar number of shocks for which compatibility of the intensity assessments was determined in the cases of the GSI-GZW $\mathrm{KW}^{-}$

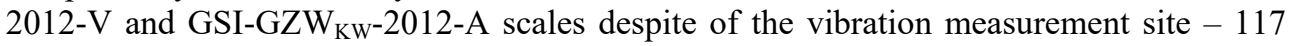
shocks $(75.0 \%$ of all) and 119 shocks $(76.3 \%$ of all) respectively. The most different assessments of vibration intensity were obtained in the cases of the rockbursts classifying to the first and the second degrees of vibration intensity according to the GSI-GZW $\mathrm{KW}-2012-\mathrm{V}$ scale. This conclusion refers both to the free-field vibrations as well as to the foundation vibrations.

Table 6. List regarding the rockbursts for which compatibility of the intensity assessments was obtained in the cases of the GSI-GZW $\mathrm{KW}_{-2012-V}$ and GSI-GZW $\mathrm{KW}-2012-\mathrm{A}$ scales.

\begin{tabular}{|c|c|c|c|c|c|}
\hline \multicolumn{7}{|c|}{ Intensity I determined on the basis of: } \\
\hline \multicolumn{2}{|c|}{ free-field vibrations } & \multicolumn{3}{c|}{ foundation vibrations } \\
\hline $\begin{array}{c}\text { Intensity } \\
I\end{array}$ & $\begin{array}{c}\text { Number of } \\
\text { shocks }\end{array}$ & $\begin{array}{c}\text { Percentage of } \\
\text { all (156) shocks }\end{array}$ & $\begin{array}{c}\text { Intensity } \\
I\end{array}$ & $\begin{array}{c}\text { Number of } \\
\text { shocks }\end{array}$ & $\begin{array}{c}\text { Percentage of } \\
\text { all (156) shocks }\end{array}$ \\
\hline 0 & 71 & $45.5 \%$ & 0 & 85 & $54.5 \%$ \\
\hline I & 39 & $25.0 \%$ & I & 25 & $16.0 \%$ \\
\hline II & 5 & $3.2 \%$ & II & 7 & $4.5 \%$ \\
\hline III & 1 & $0.6 \%$ & III & 1 & $0.6 \%$ \\
\hline IV & 1 & $0.6 \%$ & IV & 1 & $0.6 \%$ \\
\hline In total & 117 & $75.0 \%$ & In total & 119 & $76.3 \%$ \\
\hline
\end{tabular}

Table 7. List regarding the rockbursts for which compatibility of the intensity assessments was not

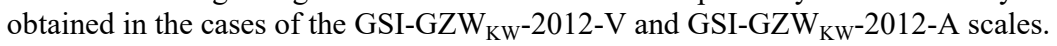

\begin{tabular}{|c|c|c|c|c|c|}
\hline \multicolumn{6}{|c|}{ Intensity $I$ determined on the basis of: } \\
\hline \multicolumn{3}{|c|}{ free-field vibrations } & \multicolumn{3}{|c|}{ foundation vibrations } \\
\hline \multicolumn{2}{|c|}{ Intensity $I$} & \multirow{2}{*}{$\begin{array}{l}\text { Number of } \\
\text { shocks }\end{array}$} & \multicolumn{2}{|c|}{ Intensity $I$} & \multirow{2}{*}{$\begin{array}{c}\text { Number of } \\
\text { shocks }\end{array}$} \\
\hline $\begin{array}{c}\text { GSI-GZW }_{\mathrm{KW}^{-}} \\
2012-\mathrm{V}\end{array}$ & $\begin{array}{c}\text { GSI-GZW }_{\mathrm{KW}^{-}} \\
2012-\mathrm{A}\end{array}$ & & $\begin{array}{c}\text { GSI-GZW }_{\mathrm{KW}^{-}} \\
2012-\mathrm{V}\end{array}$ & $\begin{array}{c}\text { GSI-GZW }_{\mathrm{KW}^{-}} \\
2012-\mathrm{A}\end{array}$ & \\
\hline 0 & I & 4 & I & 0 & 24 \\
\hline I & 0 & 23 & II & I & 10 \\
\hline II & I & 10 & II & 0 & 1 \\
\hline II & III & 1 & II & III & 1 \\
\hline III & IV & 1 & III & IV & 1 \\
\hline \multicolumn{2}{|c|}{ In total } & $39(25.0 \%)$ & \multicolumn{2}{|c|}{ In total } & $37(23.7 \%)$ \\
\hline
\end{tabular}




\section{Conclusions}

Carried out analyses show that significant differences can occur in the cases of approximate classification (using of GSI-GZW $\mathrm{KW}_{\mathrm{W}} 2012$ scale) of mining tremors harmfulness based on the free-field vibrations and simultaneously measured building foundation vibrations. The most of incompatibilities in assessments of vibration intensity (degree of intensity) are observed in the cases of the first and the second degree of vibration intensity. Whereas the good compatibility of classification of vibration intensity on the basis of free-field or foundation vibrations is visible in the cases of very weak rockbursts (with vibration intensity of degree 0) and, on the other hand, in the cases of very strong shocks (with vibration intensity of degree III and IV). However, because of the small number of vibrations with high degree of intensity (III and IV degree) in the set of considered mineinduced vibrations, the conclusions regarding such vibrations require verification in the future investigations.

\section{References}

1. E. Maciag, K. Kuźniar, T. Tatara, Earthquake Spectra 32, 3, 1769-1791 (2016)

2. A. Biessikirski, Przegląd Górniczy 6, 1-6 (2014)

3. J. Dubiński, K. Jaśkiewicz, A. Lurka, G. Mutke, Górnicza skala intensywności sejsmicznej GSI-2004/11 dla wstrząsów górniczych w LGOM. [in:] Weryfikacja skal GSI-2004, Wrocław: KGHM CUPRUM sp. z o.o. - CBR, 150-169 (2011) (unpublished work)

4. J. Dubiński et al., Weryfikacja skal GSI-2004, KGHM CUPRUM sp. z o.o. - CBR, (Wrocław 2011) (unpublished work)

5. I. Jaśkiewicz-Proć, Przegląd Górniczy 6, 14-23 (2014)

6. K. Kuźniar, T. Tatara, Procedia Engineering 199, 2378-2383 (2017)

7. K. Kuźniar, E. Maciąg, T. Tatara, First European Conference on Earthquake Engineering and Seismology (ECEES), Geneva, Switzerland, Abstract Book, 466-467 (2006) (full paper on CD)

8. K. Kuźniar, T. Tatara, Przegląd Górniczy 10, 31-36 (2015)

9. E. Maciąg, Inżynieria Morska i Geotechnika 4, 240-250 (2006)

10. E. Maciąg, K. Kuźniar, T. Tatara, [in:] Stypuła K. (ed.), Aktualne problemy wpływów sejsmicznych i parasejsmicznych na budowle. Badania wstrząsów górniczych i drgań komunikacyjnych, 477/2, Seria Inżynieria Lądowa, 39-66 (Wyd. PK, Kraków, 2015)

11. T. Tatara, Odporność dynamiczna obiektów budowlanych w warunkach wstrząsów górniczych (Wydawnictwo PK, Kraków 2012)

12. E. Maciąg, Inżynieria i Budownictwo 12, 670-677 (2005)

13. A. Barański, L. Kloc, T. Kowal, G. Mutke, Bezpieczeństwo Pracy i Ochrona Środowiska w Górnictwie 6, 3-10 (2014)

14. A. Barański, L. Kloc, T. Kowal, G. Mutke, Bezpieczeństwo Pracy i Ochrona Środowiska w Górnictwie 11, 32-33 (2014)

15. J. Dubiński, G. Mutke, T. Tatara, L. Muszyński, A. Barański, T. Kowal, Zasady stosowania zweryfikowanej Górniczej Skali Intensywności drgań GSI-GZW $\mathrm{KW}_{\mathrm{W}}-2012$ do prognozy i oceny skutków wstrząsów indukowanych eksploatacją złóż węgla kamiennego w zakładach górniczych Kompanii Węglowej S.A. na obiekty budowlane i na ludzi, Kompania Węglowa, Katowice (2013) (unpublished work) 